\title{
The restoration of degraded forests in Ghana: a case study in the Offinso forest district
}

\author{
Baatuuwie, N. B ${ }^{1}$, Asare, N. A. ${ }^{2}$, Osei, E. M. Jnr ${ }^{3}$, Quaye-Ballard, J. A. ${ }^{3}$ \\ ${ }^{1}$ Faculty of Renewable Natural Resources, University for Development Studies, Tamale, \\ Ghana \\ ${ }^{2}$ Department of Wildlife and Range Management, College of Agriculture and Natural \\ Resources, KNUST, Kumasi \\ ${ }^{3}$ Department of Geomatic Engineering, College of Engineering, KNUST, Kumasi
}

\begin{abstract}
Natural regeneration of socio-economic valuable native tree species was studied in plantations and an adjacent degraded forest at Afram Headwaters Forest Reserve in the Ashanti Region of Ghana. The study tested the hypothesis that density and diversity of key native tree saplings differ in the different plantation stand types. A total of 40 plots $(15 \times 15 \mathrm{~m})$ were studied in monoculture of exotic species, mixed native species plantations and an adjacent degraded forest. A total of 52 naturally regenerated native tree species were recorded underneath the two plantation stands and the degraded forest with densities ranging between 4711 and 19867 saplings/ha. Eight most valuable socio-economic native sapling species were found to be among this number with densities ranging between 400 and 1022 individuals/ha in the different stands. There was no significant difference among plantation stands with regard to understory socioeconomic native saplings density (at Kruskal-Wallis test, $\alpha=0.05$ ). The study also pointed out that no significant differences exist between the diversity of the socio-economic native tree saplings regenerating naturally under the two plantation stand types at Kruskal-Wallis test, $\alpha=0.05$. The results support the perception that forest plantations can foster the regeneration of native woody species.
\end{abstract}

Keywords: Saplings, Monoculture, Native species

\section{INTRODUCTION}

The degree of deforestation and forest degradation is more swift and vast in the developing tropical countries (FAO, 2005). It is estimated that 350 million hectares of tropical forestland have been severely damaged that forests will not grow back naturally (ITTO, 2002).

The reduction and degradation of the tropical forest affect not only the production of timber but also the global environment as a whole. The loss of biological diversity, both plants and animals through forest degradation threatens the sustainable and harmonious development of the global ecosystem (Lamb \& Glimour, 2003). With this current rate of deforestation and degradation, it is anticipated that about 3 to 8 million biological species, including a large number of as-yet unknown species, will be wiped off from the surface of the earth by the end of the 21st century if measures are not put in place (Kobayashi, 2004).
In many tropical countries, this loss of the natural forests has been counteracted by the rapid increase in degraded forestland allocated to plantation establishment and other policies (FAO, 2007)

Like many other tropical countries, the loss of Ghana's natural forests has been counteracted by comprehensive reform programmes in the forestry sector (MLF, 2004). Key among the reforms was the Government's initiative in plantation establishment in the country. Plantation forestry can be used as a tool not only to halt forest degradation but also to catalyze important native forest flora restoration after long period of anthropogenic and non-anthropogenic disturbances (Lemenih \& Teketay, 2004).

The benefits of plantations to mankind cannot be overemphasized. They vary from domestic woods supply, industrial development to an increased in tree cover and reclamation of degraded land (Lamb \& Glimour, 2003). It is worth mentioning that plantations have positive effect in increasing global biodiversity (Hartley, 2002; Messier et al., 2003). 
Notwithstanding the fact that plantations have innumerable benefits, several concerns have been raised by ecologist about their stability and sustainability (Lugo et al, 1988). Most queries often raised against the use of forest plantations usually hub around their negative effects such as; low stability, low level of biodiversity, and the tendency of exotic species used for plantations to allegedly displacing valuable indigenous tree species (Lugo et al, 1988; Berger, 1993; Smith, 1994). These are arguments set to defame the expansion of plantations, especially in the tropical regions where biologically rich tropical natural forests may be replaced with biologically poor plantation stands (Armstrong \& van Hensbergen, 1996).

Ironically to the above objection about forest plantations, research in some tropical countries proofed that forest plantations could be used to contribute significantly to local and national economy through income diversification and wood and nonwood industry expansions (Lemenih \& Teketay, $2004 b)$. This is largely true because plantations enhance the recruitment; establishment and succession of socio-economic valuable native woody species by functioning as foster ecosystems thereby increasing diversity and productivity of native tree species that are beneficial to the society (Fimbel \& Fimbel; 1996; Lugo; 1997; Otsamo, 2000; Kanowski, 2005, Parrotta, 1992 and 1995). Forest plantations established on degraded sites that have been without native tree cover can act as successional catalysts, facilitating the recolonisation of native flora through their influence on understory microclimate, soil fertility, suppression of dominant grasses and provision of habitats for seed dispersing animals (Parrotta, 1995). When these natural processes are augmented by silvicultural and other management practices, can enhance the recolonisation of native tree species and the plantations may progressively be transformed to a forest resembling that of a nearby natural forest (Yirdaw, 2000, Lemenih \& Teketay, 2004).

Natural regeneration of native tree species under forest plantations can be influenced by a varied number of factors. One of these factors is the plantation design and management practices (Parrotta, 1995). These encompasses, tree spacing, the plantation age (Lugo et al.1993), understory management intensity and the degree of protection against anthropogenic and non-anthropogenic perturbations (Brown \& Lugo, 1994) as well as the plantation overstory species composition (Lugo et al. 1988).

Different overstory plantation species have different capabilities in enhancing recolonisation of understory native tree species. Some plantation species are believed to have higher potential to facilitate rapid restoration of forest plant and/or tree community; while others have no effect on increasing species diversity (Fimbel \& Fimbel, 1996). It has been reported that understory vegetation species diversity is most likely to be a function of the individual characteristic of the plantation species than variables related to landscape, site quality and viable seed source (Haggar et al., 1997; Lemenih et al., 2004). This study assessed the influence of overstory species composition on natural regeneration of valuable socio-economic native tree saplings in plantations stands of single exotic (Cedrela odorata and Tectona grandis) and mixed stands (Khaya grandifoliola, Antiaris toxicaria, Ceiba pentandra, Triplochiton scleroxylon, Terminalia superb, Terminalia ivorensis and Anopyxis klaineana) of native species in the study area.

The plantation establishment had been in full swing since the 90s with one of the main aims of restoring lost indigenous tree species that were used by local people for livelihood. Nevertheless, there is limited information regarding the performance of these plantations in rejuvenating the valuable socioeconomic native tree species that are the mainstay of the local people in the study area. Therefore the need for this study to provide information on their success for future restoration techniques, design, planning and decision making. To achieve the above aim of the study, the follow objectives were set:

- To identify native tree species of key importance for local communities in the study area

- To assess the density and diversity of naturally regenerated saplings of these key native tree species in the two plantations stand types.

\section{METHODS}

Study Area: The study was conducted in the Afram Headwaters Forest Reserve located in the Offinso District of Ashanti Region of Ghana. The Reserve lies between longitude $1^{\circ} 32^{\prime} \mathrm{W}$ and $1^{\circ} 48 \mathrm{~W}$ and latitude $6^{\circ} 45^{\prime} \mathrm{N}$ and $7^{\circ} 25^{\prime} \mathrm{N}$. It covers 20,100 hectares, comprising both natural and plantation forests. The reserve is fringed by eight villages, with their 
inhabitants depending heavily on the reserve for sustenance. Each of the communities has a population size not less than 600 people (Ghana Statistical Service, 2000).

The area experiences semi-equatorial conventional climate. Two rainfall seasons are experienced in the district. The major rains start from April to July and the minor from September to Mid- November. Annual rainfall ranges from $1500 \mathrm{~mm}$ in the north to $1700 \mathrm{~mm}$ in the south. Relative humidity is high during the major rainy season, reaching its peak of $90 \%$ between May and June.

A maximum temperature of $30^{\circ} \mathrm{C}$ is experienced between March and April, mean monthly temperature is about $27^{\circ} \mathrm{C}$.

Soils characteristics of the reserve are generally uniform with most of the Reserve consisting of reddish-brown sandy loams and occasionally patches of clay occurrences (FSD, 1985). The western part of the area overlies the rock of the upper and lower Birrimian series whiles the other parts overlies the upper Voltain sandstones (FSD, 1985). They are well-drained and support the cultivation of food crops and trees. This may be one of the contributing factors that led to the degradation of the reserve as some of the forest fringe communities were involved in illegal agriculture in some parts of the reserve.

Sampling procedure for identifying the key native tree species: A focus group discussion with local people was held to identify 'key' (the most useful socio-economic) native species commonly used in the study area. Forest fringe communities were the main targets. This was because they are the people involved in the initial establishment and management of the plantations and their needs or desires must be taken into consideration for successful restoration programme (Lamb \& Gilmour, 2003). Four forest fringe communities (Asempaneye, Kwapani, Asuboi and Apenten) were selected and focus groups comprising 8-12 (Kitzinger \& Barbour, 1999) members were formed using snowball technique (Lindlof, 1995).

The discussion of the focus group was basically guided by a checklist to identify the key native tree species and their major uses in the area. Eight people from each community within the group were randomly selected after the group discussion to rank the species listed by the group in order of preference. The ordinal ranking of the individual respondents were assigned weight for all the communities, put together and then re-ranked. Mean weight of species were computed and the overall ranking performed (Blay et al., 2007). The species with the highest mean weight was graded the most valuable and commonly useful native tree species among the forest fringe communities and the vice versa.

Sampling procedure for plantations understory assessment: Purposive sampling method was used to sample the forest stand types (monoculture plantation of teak, mixed stand of indigenous species and the natural forest) for the natural regeneration assessment. Plantations with homogeneous age (11 years old), edaphic, topographic and climatic microhabitat characteristics were selected for the regeneration assessment to avoid influences of these factors (Parrotta, 1995; Lugo et al.1993). With the exception of the natural forest, the two plantation stand types were replicated three times. To define the sample population, an hp IPAQ was used to move around the different plantation stand types (mixed stands and the teak monoculture) that are homogeneous. These created polygons of the plantation stand types (Figure 1) that were used for the sample plots allocation for the natural regeneration assessment of the native tree species within the various plantation stand types. In all six (6) polygons were created in the two plantation stand types and their replicates. 
Agric. Biol. J. N. Am., 2011, 2(1): 134-142

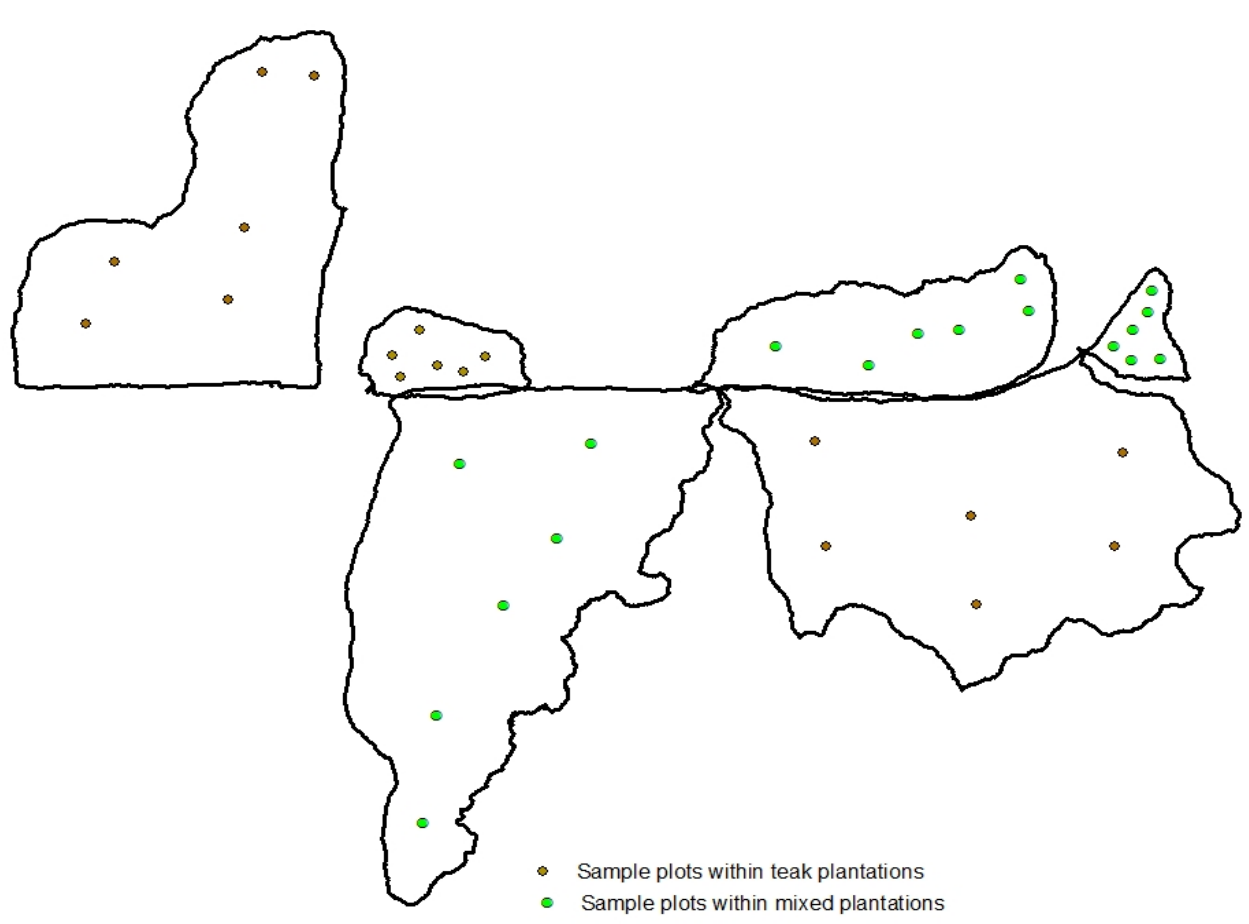

Fig 1 Polygons of the plantation stand types

Sample plots were allocated randomly using the coordinate method. A sampling tool in ArcMap called Hawths was used to generate random points in each polygon of the plantation stand types. The tool randomly select coordinates for each of two axes (X, $Y)$. The point at which these intersect specifies the location of a sample plot / Quadrat (Figure 1). According to (Elzinga, et.al., n.d) this method will work better when square plots are used and therefore suitable for this study.

Plot/Quadrat size and shape: The size of a sample plot varied from vegetation type to another (Kent \& Coker, 1992). A minimum plot/quadrat size of $20 \times 20$ meters is recommended for inventorying mature trees. For this study, a $15 \times 15 \mathrm{~m}\left(225 \mathrm{~m}^{2}\right)$ plot/Quadrat was used for the assessment of saplings diversity and density since identification and enumeration of saplings is much more difficult and time consuming than mature trees. Square plots recommended especially when the study involves species identification and counts were used to minimize edge effects of the plot/quadrat (Elzinga, et al.,n.d). A total of 40 sample plots/Quadrats were layed in the two plantation stand types and in the degraded forest for the regeneration assessment. That is six plots/Quadrats for each replicate.
Saplings identification and count: Native tree saplings regenerating under the plantations with height between 1.5-3.0 meters tall (Senbeta, 2002) were identified to species with the aid of a local botanist and other field manuals (Hawthorne, 1999). The saplings were also enumerated in each sample plot. Dead/wilted saplings were not considered due to difficulty in identifying them. Saplings were chosen for the research because at the sapling stage, they are able to tolerate and survive abiotic and biotic hazards such as soil-water stress, forest fire, herbivory and diseases and are the candidates of the forest overstory (Bunyavejchewin, 1984).

Other auxiliary data/information was also recorded within the sample plot. The overstory stand composition, presence of seed trees, planting distances of the planted trees and the general condition of the forest were taken note of. Planting distances for the plantation crop was however $3 \times 3 \mathrm{~m}$ for all the stand types.

Diversity Indices : Measuring the number and modelling the abundances of tree species per unit area makes use of diversity indices. A number of different diversity indices exist. Shannon-Weiner $\left(\mathrm{H}_{0}\right)$, Simpson and Berger-Parker indices as 
described by various authors are examples of diversity indices. The differences in these indices stemmed from their ways of combining species richness and evenness, and some indices are more influenced by richness whereas others are more influenced by evenness (Kindt, 2002). ShannonWiener's index (Shannon, 1948) which is widely used and recommended for various ecological studies was adopted for this research. Equation 1 below is used in calculating Shannon index (Kent \& Cooker, 1992).

$$
H^{\prime}=-\sum_{i=1}^{s} P_{i} \operatorname{In} P_{i} \quad \text { Equation } 1
$$

Where:

$P_{i}$ is the proportion of individuals from the $i^{\text {th }}$ species.

$S$ is the number of species

In is the log base $n$

Analysis of data on regeneration diversity and density: Valuable socio-economic native tree species regenerating naturally under the different plantations and the degraded forest (control) stand types were compared. Descriptive statistics of each forest stand type was performed first to compare the mean/median densities and Shannon's index of the socio-economic native species. Non-parametric statistical test, using Kruskal-Wallis test was performed to find out if the medians of the densities and Shannon indices are different between the different forest stand types. The Kruskal-Wallis test is a counterpart of Analysis Of Variance principally applied to test for significance variations in median of a sample population when the data shows abnormal (skewed) distribution (Moore \& McCabe 2007). Dunn's Multiple Comparison Test was employed to test for where the median understory native tree species density and Shannon's indices of the forest stand type are significant.

\section{RESULTS}

Most useful key native tree species in the area: The most useful and preferred ten (10) native tree species identified by the local people are presented in Table 1. Milicia excels (Odum) was rated the best and most preferred native tree species with a mean weight of 11.4. Antiaris toxicaria (Kyenkyen) was rated the least among the ten species with mean weight of 3.6.

Table 1: The most useful top ten key native tree species

\begin{tabular}{|l|l|l|c|}
\hline S/N & Local name & Scientific name & Mean Weight \\
\hline 1 & Odum & Milicia excelsa & 11.4 \\
\hline 2 & Mahogany & Khaya grandifoliola & 10.5 \\
\hline 3 & Dahoma & Piptadeniastrum & 10.2 \\
\hline 4 & Edinam & Entandophragma angolense & 10.1 \\
\hline 5 & Kokrodua & Pericopsis elata & 9.0 \\
\hline 6 & Asamfena & Pouteria spp & 7.8 \\
\hline 7 & Emire & Terminalia ivorensis & 7.6 \\
\hline 8 & Ofram & Terminalia superba & 6.5 \\
\hline 9 & Efoobrodedwo & Entandrophragma utile & 3.6 \\
\hline 10 & Kyenkyen & Antiaris toxicaria & \\
\hline
\end{tabular}

\section{Saplings Diversity Estimation}

In general 52 species of native tree saplings were identified and counted in all the forest stand types in the study area. Out of this, eight (8) of the top ten key native species mostly preferred by the forest fringe communities were found in the different forest stand types. All the stand types have equal representation of four (4) species each.
Table 2 however revealed significant variation between the median Shannon indices of the top ten native tree saplings in the different forest stand types. The P-value of 0.002 confirmed that, there is significant difference between two forest stand types at (Kruskal-Wallis test, $\alpha=0.05$ ). Teak plantation stand type had the least median Shannon index of 0.24 while degraded forest/control had the highest median value of 3.61 . 
Agric. Biol. J. N. Am., 2011, 2(1): 134-142

Table 2: Kruskal-Wallis test of the Shannon indices of the top ten native tree saplings

\begin{tabular}{|l|c|c|c|c|c|c|}
\hline Forest stand types & Minimum & Maximum & Median & $\begin{array}{c}\text { Std. } \\
\text { Deviation }\end{array}$ & Std. Error & P value \\
\hline Mix & 0 & 0.76 & 0.35 & 0.24 & 0.10 & 0.002 \\
\hline Teak & 0 & 0.35 & 0.24 & 0.15 & 0.06 & \\
\hline Control & 1.87 & 4.82 & 3.61 & 1.01 & 0.41 & \\
\hline
\end{tabular}

Dunn's multiple comparison test of the Shannon indices of the top ten native tree saplings

The Dunn's multiple comparison tests in Table 3 showed that there is no significant difference between the Shannon indices of mixed and teak stand types. Shannon indices of teak stand type and the control varied significantly as the $p$-value is $<0.05$ (Kruskal-Wallis test, $\alpha=0.05$ ). Also no significant difference exist between mixed stand type and the control as the $p$-value is $>0.05$

Table 3: Dunn's Multiple Comparison Test of the Shannon indices of the top ten saplings between the forest stand types

\begin{tabular}{|l|c|c|c|}
\hline $\begin{array}{l}\text { Forest stand } \\
\text { types }\end{array}$ & $\begin{array}{c}\text { Difference } \\
\text { in rank } \\
\text { sum }\end{array}$ & P value & Summary \\
\hline Mixed vs Teak & 3.33 & $\mathrm{P}>0.05$ & $\mathrm{Ns}$ \\
\hline $\begin{array}{l}\text { Mixed vs } \\
\text { control }\end{array}$ & -7.33 & $\mathrm{P}>0.05$ & $\mathrm{Ns}$ \\
\hline Teak vs control & -10.67 & $\mathrm{P}<0.05$ & Sig. \\
\hline
\end{tabular}

Kruskal-Wallis test of the Saplings densities of the top ten native tree species in the different forest stands.

Densities of the top ten native tree species in Table 4 indicated that there is no variation between the medians (4) of the mixed stand types and that of the control (degraded forest). However there is a variation between medians of these two forest stand types (mixed and control) and the teak stand types. The teak had the lowest median of 2.00.

Subsequently, Kruskal-Wallis test showed that there is no significant difference among the median densities in the three different forest stand types. This is evidenced as the $p$ - value of 0.2797 according to the Kruskal-Wallis test at $\alpha=0.05$.

Ns: not significant Sig: significant.

Table 4: Kruskal-Wallis test of the density of the top ten native tree saplings in the forest stand types

\begin{tabular}{|l|c|c|c|c|c|c|}
\hline Forest stand types & Minimum & Maximum & Median & $\begin{array}{c}\text { Std. } \\
\text { Deviation }\end{array}$ & Std. Error & P-value \\
\hline Mix & 2 & 14 & 4 & 5.56 & 3 & 0.2797 \\
\hline Teak & 1 & 4 & 2 & 1.50 & 1 & \\
\hline Control & 2 & 14 & 4 & 5.42 & 2.71 & \\
\hline
\end{tabular}

\section{DISCUSSION}

Most useful key native tree species in the area:

The most useful and preferred ten (10) native trees species identified by the local people are presented in Table 1above. These species are among the list of known Ghanaian tree species used mainly by local people within the forest zone for construction, medicine, insecticide, furnishing business and other domestic purposes which are gradually getting extinct due to deforestation and forest degradation (TED, 1997; FAO, 2000). High preference was given to tree species that have multiple uses. They bring more economic returns in the form of cash to the local people. This has confirmed the findings by Blay, (2004), that trading in non-timber forest products (chewing sticks, pestles, canes, nuts, fruits, bush meat, fodder, artefacts, medicine, etc., extracted from the forest) is economically important within all areas of the high forest zone in Ghana.

Since these species are the mainstay of the local people, any restoration programme that will lead to an increased in the regeneration of these key native tree species will directly or indirectly improve the livelihood of these forest fringe communities (TBIGhana, 2007). Also, the benefits that will be accrued to these forest communities as a result of restored 
forest, if significant is likely to influence and motivate communities' participation in future restoration programmes as reported by Lamb \& Gilmour, (2003).

\section{Diversity of the top ten native tree saplings in the different forest stands}

It was anticipated in this study that diversity of the key native tree species will differ in the different plantation stand types in the study area. But the results obtained from the study however pointed out that no significant differences existed between the diversity of the top ten socio-economic native tree saplings regenerating naturally under the two plantation stand types (mixed and teak stand types). That is, both plantation stand types have proofed to have equal potentials in facilitating the regeneration of the key native tree species with regard to their diversity. This insignificant difference could be due to the similar spacing and management measures put in place for both plantation stand types. Apart from climatic, edaphic, and other factors, plantation design and management practices as reported by (Parrotta, 1995; Lugo et al.1993) are very important factors influencing the diversity of native tree species beneath forests plantations.

Compared to the control (degraded forest) significant differences exist between the diversity indices of teak stand type and that of the control. The mixed plantation stands and the control showed no variation in diversity of the top ten native sapling species under them. This could be due to the fact that both the control and the mixed stand plantation have similar overstory species composition. This suggested that, the plantation overstory composition has an influence on the diversity of the top ten native species in the area. This result agrees with Lugo et al. (1988) who reported that plantation overstory species composition is one of the major factors influencing natural regeneration beneath the plantations.

The control however showed slightly higher diversity index than the two plantation types. This difference may be attributed to the intensity of the site preparation methods used during initial plantation establishment. In these plantations, farm implements used may have greatly distorted some important features of the stand biological inheritance (Franklin et al., 2000). Ploughing or hoeing during site preparation in plantations has been reported to have an important impact on tree diversity (Hartley, 2002). Such soil modification mainly destroys the established flora and reduces soil surface heterogeneity. This may consequently reduce habitat diversity and may hamper understory native tree species establishment through environmental limitations (Flinn \& Vellend, 2005; Flinn \& Marks, 2007).

Also silvicultural practices in plantations, such as thinning, pruning and weeding, have been reported to have an important impact on diversity of underneath tree species (Hartley, 2002). Although these factors were not specifically tested in this study, they may have contributed to the low diversity of these native tree saplings in the two plantations (Teak and mixed stand). Thus continuous disturbance of the seed bank in the soil within the first three years of plantation establishment may have interrupted the germination and establishment of these key native tree species which cannot withstand continuous perturbations (Hawthorne, 1995; Senbeta et al.2002). The Shannon-Wiener diversity index is also believed to be sensitive to numerical dominance by any species and for this reason the diversity values of these stands were reduced due to many individuals of a few species (Bone et al.1997).

Saplings Density estimation of the top ten native tree species in the different forest stands: The two plantations types as well as the control (degraded forest) showed no significant difference in terms of recolonisation potential or understory density of the top ten socio-economic most valuable native tree saplings $(p=0.2797$ at Kruskal-Wallis test, $\alpha=0.05)$. Thus the two plantation stand types as well as the degraded forest have equal abilities in supporting natural regeneration of these valuable socioeconomic native tree species under them. This similarity in abilities among the forest stand types in supporting saplings density may stemmed from the dispersal ecology (the mode and agents of the seed dispersal) of these valuable socio-economic native tree species. The mechanism of Seed dispersal is reported to play an important role in the process of regeneration of underneath native tree species than seed banks under forest plantations (Lemenih and Teketay, 2004). From the ecological perspective, about $80 \%$ of these top ten native tree species belong to a category of seeds that depend largely on the wind as the mechanism for their seed dispersal (Howthorn 1995). Seeds dispersed by wind reach far distances within a short period of time and are most often uniformly distributed over an area. This may be the cause of the approximately equal densities of top 
ten native tree saplings found within the three forest stand types.

\section{CONCLUSIONS AND RECOMMENDATIONS}

The most useful and preferred ten (10) native trees species identified by the local people in the study area are: Entandophragma angolense, Entandrophragma utile, Milicia excels Pouteria spp and Piptadeniastrum spp. The rest are Terminalia ivorensis, Pericopsis elata, Khaya grandifoliola, Terminalia superb and Antiaris toxicaria. High preference was given to these tree species because they bring high economic returns in the form of cash to the local people. They are therefore considered as the mainstay of these local people within the forestfringe communities.

With regards to the top ten native tree saplings diversity, both plantation stand types have proofed to have approximately equal potentials in supporting the diversity of these species under them. Comparing the plantations to the control/degraded forest, the control however showed higher supportive ability in diversity of the top ten native tree saplings than the two plantation types.

In contrast, the two plantations types as well as the control (degraded forest) showed no significant difference in terms of recolonisation potential or understory densities of the top ten native tree saplings. It is therefore concluded that all the forest stand types have comparable abilities in supporting saplings densities of the top ten socio-economic valuable native tree species in the study area.

The following recommendations were made; the outcome of this study shows that plantations can facilitate the regeneration of native tree species under their canopy in terms of species density and diversity, and thereby is recommendable for use as a tool to rehabilitate degraded forests in Ghana. In addition, mixed-species plantations are recommended for restorations as they show high proficiency in accelerating the restoration process. Where monoculture plantations will be employed, it is recommended that intensive management principles such as thinning and others should be adhered to that will create conditions similar to that of the mixed plantation stands or a natural forest that will facilitate the recovery of native tree species under them.

\section{REFERENCES}

Anonymous. (1996). World Conservation Monitoring Centre, 1992. Global biodiversity. Status of the earth's living resources. Chapman and Hall, London.

Berger, J.J. (1993). Ecological restoration and nonindigenous plant species: a review. Rest. Ecol. 1:7482.

Blay.D, Appiah, M., Damnyag, L., Dwomoh, K.F. \& Ari Pappinen, L. O. (2007). Involving local farmers in rehabilitation of degraded tropical forests: some lessons from Ghana.

Bone L., Lawrence, M. \& Magombo, Z. (1997). The effect of a Eucalyptus camaldulensis Dehnh, plantation on native woodland recovery on Ulumba Mountains, Southern Malawi. For. Ecol. Manage.99: 83-99.

Brown, S. \& Lugo, A.E. (1994). Rehabilitation of tropical lands: a key to sustaining development. Restor. Ecol. 2:97-111.

Bunyavejchewin, S. (1984). Structure and growth in teak forest 10 years after logging in Thailand 197-211. Thailand.

Elzinga, L. C., Salzer, W. D., \& Willoughby, W. J., Measuring and Monitoring Plant Populations. Bureau of Land Management Technical Reference 1730-1. BLM/RS/ST-98/005-1730

FAO (2007). State of the world's forest, seventh ed. Food and Agriculture Organization of the United Nations, Rome

FAO (2005). Global Forest Resources Assessment. Progress towards sustainable forest management.

Ghana Statistical Service. (2000). Summary of the 2000 Population Census Report. Accra; Ghana: Ghana Statistical Service.

FAO (2000). Global forest resources assessment main report. FAO Forestry Paper 140, 479 pp.

Flinn, K.M., Marks, P.L. (2007). Agricultural legacies in forest environments: tree communities, soil properties, and light availability. Ecological Applications 17, 452463.

Flinn, K.M., Vellend, M. (2005). Recovery of forest plant communities in post-agricultural landscapes. Frontiers in Ecology and the Environment 3, 243-250

Franklin, J.F., Lindenmayer, D., MacMahon, J.A., McKee, A., Magnuson, J., Perry, D.A., Waide, R., Foster, D. (2000). Threads of continuity: ecosystem disturbance, recovery, and the theory of biological legacies. Conservation Biology in Practice 1, 8-16.

Fimbel, A. R. \& Fimbel, C. C. (1996). The role of exotic conifer plantations in rehabilitating degraded tropical forest lands: A case study from the Kibale Forest in Uganda 
ITTO. (2002). ITTO guidelines for the restoration, management and rehabilitation of degraded and secondary tropical forests. ITTO Policy Development Series.

Kanowski, P. (2005). Intensively managed forests. A report prepared for the forest dialogue, Yale University, Connecticut, United State, and June 2005.

Kent, M. and P. Coker. (1992). Vegetation Description and Analysis: a practical approach. Belhaven Press, London

Kindt, R. (2002). Methodology for tree species diversification planning for African agroecosystems. $\mathrm{PhD}$ thesis. Ghent University

Kitzinger, J. \& Barbour, R. S. (1999). Introduction: The challenge and promise of focus groups. In (Eds.) Barbour, R. S. and Kitzinger, J. Developing focus group research: Politics, theory and practice (pp. 120). London: Sage.

Kobayashi, S. (2004). Landscape Rehabilitation of Degraded Tropical Forest Ecosystems. Case Study of the CIFOR/Japan Project in Indonesia and Peru. Tsukuba, Ibaraki, Japan.

Lamb, D. \& Gilmour, D. (2003). Rehabilitation and Restoration of Degraded Forests. IUCN, Gland, Switzerland and Cambridge, UK and WWF, Gland, Switzerland. $110 \mathrm{pp}$.

Lemenih, M. \& Teketay, D. (2004b). Restoration of native forest flora under plantation forests established on abandoned degraded agricultural sites in Ethiopia. Environmental management.

Lemenih, M., Gidyelew, T. \& Teketay, D. (2004). Effects of canopy cover and under-canopy micro-climate factors of tree plantations on the composition, density and growth of native woody species in the southern highlands of Ethiopia. For. Ecol. Manage.

Lindlof, T. R. (1995). Qualitative communication research methods. Thousand Oaks: Sage.

Lugo, A. E. (1997). The apparent paradox of reestablishing species richness with tree monocultures. 99, 99-19.

Lugo, A.E., Brown, S. \& Chapman, J. (1988). An analytical review of production rates and stemwood biomass of tropical forest plantations. For. Ecol. Manage. 23:179200.

Lugo A.E., Parrotta J.A. \& Brown S. (1993). Loss in species caused by tropical deforestation and their recovery through management. AMBIO 22: 107-109.

Messier, C., Bigue, B. \& Bernier, L. (2003). Using fastgrowing plantations to promote forest ecosystem protection in Canada. Unasylva 54, 59-63.
MLF. (2004). Criteria and Indicators for Sustainable Management of Natural Tropical Forests. Ghana

Moore, D. S. \& McCabe, P. G. (2007). Introduction to the practice of statistics (sixth ed.). New York.

Otsamo.R. (2000). Early development of three planted indigenous tree species and natural understory vegetation in artificial gaps in an Acacia mangium stand on an Imperata cylindrica grassland site in South Kalimantan, Indonesia. University of Helsinki, Department of Forest Ecology/Tropical Silviculture.

Parrotta, A. J. (1992). The role of plantation forests in rehabilitating degraded tropical ecosystems Volume 41(Issue 2), 115-133.

Parrotta, J. A. (1995). Influence of overstory composition on understory colonization by native species in plantations on a degraded tropical site 6 (5), 627-636

Haggar, J. P, Powers, F.S. \& Fisher, R.F. (1997). The effect of overstorey composition on understory woody regeneration and species richness in 7-year-old plantations in Costa Rica. For. Ecol. Manage. 99:4354.

Hartley, M.J. (2002). Rationale and methods for conserving biodiversity in plantation forests. Forest Ecology and Management 155, 81-95.

Hawthorne, W. (1999). Field guide to the forest trees of Ghana. ODA/NRI. Ghana Forestry Series, Accra, Ghana.

Hawthorne, W D. (1995). Ecological profiles of Ghanaian forest trees, tropical forestry papers- Abingdon, UK: Nuffield Press.

Senbeta, F., Teketay, D \& Naslund, B. (2002). Native woody species regeneration in exotic tree plantations at Munessa-Shashemene Forest, southern Ethiopia. New Forests 24: 131-145. The Netherlands.

Shannon, C. E. (1948). A mathematical theory of communication. Bell System. Technol. J. 27, 379-423, 623-653.

Smith, C.T. (1994). Is plantation forestry good or bad for soils? New Zealand. For. 39:19-22.

TBI-Ghana. (2007). Restoration and sustainable management of forests in Ghana. Proceedings of an international conference held in Paper presented at the Tropenbos International - Ghana Workshop Proceedings 6. Kumasi, Elmina, Ghana

TED. (1997). Ghana Forest Loss. Case Studies. http://www.american.edu/TED/ghana.htm

Yirdaw E. (2000). Restoration of the native woody-species diversity, using plantation species as foster trees, in the degraded highlands of Ethiopia. Finland. 